\section{Linné som professor i medisin}

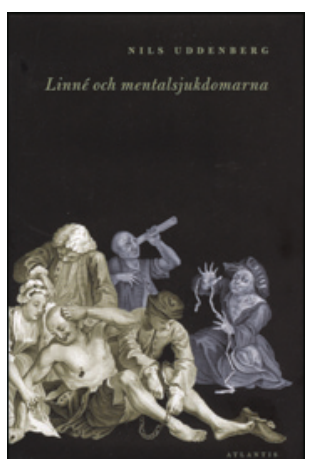

Nils Uddenberg

Linné och mentalsjukdommarna

150 s, ill. Stockholm: Atlantis bokförlag, 2012

Pris SEK 210

ISBN 978-91-7353-548-9

Den 5. mai 1741 fikk Carl Linnaeus (1707-1778) kongelig fullmakt til å være Medicinae Practices Professor $i$ Uppsala. Seks år tidligere hadde han tatt den medisinske doktorgraden i Harderwijk i Holland, og emnet var malaria. Allerede i 1735 hadde Linné publisert Systema naturea hvor plantene ble inndelt i familier, slekter og arter, noe som gjorde ham verdensberømt. Han grunnla da den første floraen, og senere floraer bygger i stor grad på denne. I 1751 utga han Species planetarum.

Likesom Descartes 100 år tidligere, hevdet Linné at naturvitenskapene burde beskjeftige seg med alt som kunne måles, veies og registreres. Som professor i medisin arbeidet Linné ikke meget som lege, men han underviste studenter. Emnet for sine første forelesninger ga han tittelen Systema morborum. Linné mente at all kunnskap var avhengig av at man kunne gjenkjenne og kategorisere det man studerte, enten det dreide seg om planter, dyr, mennesker eller sykdommer. Nosologien er kunsten å systematisere det legen tar inn ved hjelp av sine sanser, det vil si å gjenkjenne sykdommene ut i fra symptomene. Linné delte legekunsten inn i Medicina theoretica, som omhandler anatomi og fysiologi - det vil si kroppens normale funksjoner, og Medicina practica, som består i å stille en korrekt diagnose og finne riktige legemidler. Hans forelesninger var offentlige, og hvem som helst kunne høre på dem helt gratis.

Pehr Osbeck (1723-1805) var en av Linnés dyktigste elever. Denne boken er en utgave av Pehr Osbecks notater om psykiatri fra Linne?s forelesninger om temaet Systema morborum, skoleåret 1746-1747. Notatene følges av kommentarer fra forfatteren, Nils Uddeberg, som selv er professor i psykiatri. Ifølge Osbeck sa Linné at det var nødvendig for en Medicus å ha kjennskap til alle sykdommer, for i motsatt fall kunne han ikke kalle seg lege. Linné beskrev Melancholia som ifølge Uddenberg er levende skildret og fortsatt gyldig.

Linné betraktet mentale lidelser som sykdommer. Han kalte dem Morbi mentalis i sine forelesninger. De tilhørte altså medisinen. Det var skader i nervesystemet, noe som var banebrytende på den tiden hvor folk oppfattet slike sykdommer som besettelse av onde ånder, hekser eller djevelen personlig.

Boken er meget leseverdig, ikke minst for psykiatrisk interesserte personer.

\section{Elling Kvamme}

Oslo

\section{Nytt lys på mennesket}

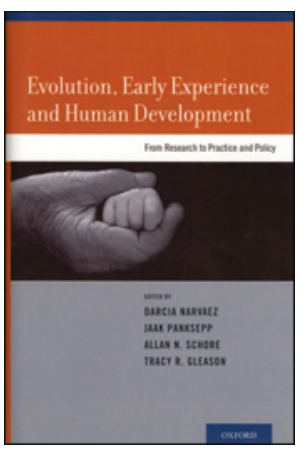

Darcia Narvaez, Jaak Panksepp,

Allan N. Schore et al, red.

Evolution, early experience and human development

From research to practice and policy. $490 \mathrm{~s}$, tab, ill. Oxford: Oxford University Press, 2012 Pris GBP 48

ISBN 978-0-19-975505-9

Hvor kommer vi fra? Hvorfor og hvordan blir vi som vi blir?

I denne ambisiøse boken stiller forfatterne slike gjennomgripende spørsmål. I lys av evolusjonsteori konsentrerer de seg i 23 kapitler spesielt om mellommenneskelige erfaringer tidlig i livet og disses betydning for senere helse. Språket er engelsk, og målgruppen er alle som er interessert i slike spørsmål.

For det første er det et evolusjonært lys. Forfatterne vil revitalisere menneskets artshistorie som klangbunn for forståelse av helseproblemer i dag. Men tankegangen her er imidlertid mindre gen- og individfokusert enn den mange forbinder med evolusjonsteori. John Bowlbys teori om tilknytning og og «environment of evolutionary adaptedness» er et utgangspunkt. Her fremstilles mennesket med sosiale behov og evner som er evolusjonært tilpasset en relasjonelt sammenvevd forfedrekontekst. Dette knyttes til en sosial nevrovitenskap, der for eksempel speilnevroner og en «psykobiologisk tilstedeværende mor» spiller hovedroller.

Et annet lys er det epigenetiske. Epigenetikk er studiet av hvordan arvematerialet DNA kan merkes molekylært og endre funksjon i møte med miljøfaktorer, blant annet menneskelige relasjoner. Biolog Michael Meaney fremstiller i et nøkkelkapittel menneskets utvikling som et livslangt, uløselig samspill mellom gener og miljø. Samspillet former funksjonen i pasienters tilpasningssystemer - nervesystemet, hormonsystemene og immunforsvaret med konsekvenser for helseproblemer i alle medisinske skott.

Psykolog Jay Belsky forklarer hvordan barn har ulik grad av genetisk mottakelighet for miljøpåvirkning. Et oppsiktsvekkende poeng her er at det som er blitt sett som dårlige risikogener, ikke bare kan gi opphav til normalitet, men også spesielt positive trekk avhengig av konteksten genomet fungerer i. Denne teorien om metaforisk robuste «løvetannbarn» og sensitive «orkidébarn» som lett kan gå til grunne, men også blomstre spektakulært, snur opp ned på det ensidige risikosøkelyset i genetisk epidemiologi. Den kaster også et forståelsens lys på potensialet som bodde eller bor i den som utvikler noe vi ser som sykt.

Dette er budskap som går mot overdreven genetisk determinisme, og som forkaster det gamle skillet mellom arv og miljø som uavhengige årsaksfaktorer. Det åpner også for et samarbeid mellom biologi, samfunnsvitenskap og humaniora med betydelig relevans for medisin.

Bak alt dette lurer også et systemteoretisk perspektiv. Mennesket ses som et emergent fenomen, noe nytt som oppstår i samspillet mellom flere faktorer over tid.

Boken har tidvis et klart politisk budskap. Enkelte forfattere kan kritiseres for overdreven miljødeterminisme og å overdrive skadevirkningene moderne oppvekst kan ha på den sosiale hjernen. Boken har imidlertid flere kapitler der forfatterne kritiserer hverandre. Den anbefales som et vindu mot nybrottsarbeid i studiet av menneskets utvikling.

\section{Henrik Vogt}

Allmennmedisinsk forskningsenhet

Institutt for samfunnsmedisin

Norges teknisk-naturvitenskapelige universitet 